\title{
SUBACUTE AND CHRONIC INFLAMMATORY IRIS NODULES DUE TO PYOGENIC BACTERIA*
}

\author{
BY \\ ALY MORTADA \\ Department of Ophthalmology, Faculty of Medicine, Cairo University, Cairo, Egyp
}

\begin{abstract}
AMSLER AND VERREY (1943) studied the cytology of the aqueous of patients with acute iritis and reported microphages laden with cocci. They reported a 4 to 8 per cent incidence of positive aqueous cultures mostly containing staphylococci and pneumococci. Verrey (1949), in a case of acute iridocyclitis, found that on the 4th day the anterior chamber showed Staphylococcus aureus, on the 9 th day agglutinated cocci, and that on the 14th day the aqueous was sterile and the micro-organisms phagocytosed by macrophages. Huber (1951) found equal parts of polymorphonuclears, lymphocytes, and tissue cells in acute endogenous uveitis, and a preponderance of lymphocytes in chronic uveitis.

Woods (1947) classified cases of endogenous uveitis as non-granulomatous and granulomatous, differentiating between the allergic and the infective (non-pyogenic) groups.

Wolff (1951) stated that iris nodules were caused by congenital melanomata, tubercle, syphilis, sarcoidosis, ophthalmia nodosa, round foreign body, leukaemia, cysts, and tumours. Busacca (1932) described floccules on the anterior mesodermal surface of the iris, composed of masses of lymphocytes and epithelioid cells but containing no organisms and entailing no tissue loss. The presence of these nodules has been associated with lowgrade uveitis, especially in cases of tubercle, syphilis, leprosy, and sympathetic ophthalmitis (Duke-Elder, 1940).

In many cases the same pyogenic organism as that causing uveitis has been cultured from the ocular tissues and the primary septic focus: pneumococci from otitis media (Lawson, 1933; Howard, 1936); staphylococci from furuncle on skin or carbuncle in the neck (Higuchi, 1934; Laval, 1937) or from urinary infection (Sédan, 1935); streptococci from dental abscess (Wood, 1925). Goh (1897) recorded a case of pneumococcal metastasis wherein one eye was lost with panophthalmitis, while the other showed mild inflammatory nodules containing masses of organisms. Raubitschek (1914) and Horner and Cordes (1931) reported an isolated abscess and Heine (1923) and Mylius (1926) reported multiple abscesses of the iris due to endogenous staphylococcal infection.
\end{abstract}




\section{Case Reports}

The four cases to be described presented, not because of the classical signs and symptoms of iritis, but because of an iris nodule which was misdiagnosed clinically as a tuberculoma. There was no ocular pain, lacrimation, photophobia, ciliary injection, or hypopyon. The visual acuity was not affected. The pupil was round, active, and dilated regularly with homatropine. There were no posterior synechiae. The lens and vitreous were clear, and the fundus and ocular tension normal. The conjunctival smear and culture were negative for organisms.

Slit-lamp examination did not reveal aqueous flare or keratic precipitates. There was no iris loss of pattern, change of colour, or new vessels. The iris nodule was single, round, yellow, not vascularized or pigmented, 2 to $3 \mathrm{~mm}$. in size, and was situated on the anterior mesodermal surface of the ciliary border of the iris, filling the angle of the anterior chamber. In Cases 1 and 3 the contact of the nodule with the posterior corneal peripheral surface caused an endothelial disturbance giving a small 2-mm. area of keratitis profunda.

The general health was good. There was no previous history of eye disease, important family history, fever, herpes, or skin affection. There was no enlarged lymph glands, spleen, liver, or salivary glands. The chest and abdomen were normal. There were no tumours in the body. There was no clinical or laboratory evidence of tuberculosis, syphilis, sarcoidosis, brucellosis, toxoplasmosis, parasitic infection, dysentery, rheumatism, gout, gonorrhoea, or diabetes. There were no signs of leprosy, allergy, Behçet's syndrome, or the Vogt-Koyanagi-Harada syndrome. Only in Case 4 was there a history of injury.

Total and differential blood counts and erythrocyte sedimentation rates were normal. The blood Wassermann reaction was negative. The tuberculin test in most of the cases was positive. $\mathrm{X}$ rays of the chest and long and short bones were normal. The urine was free from albumen, sugar, and uric acid. The teeth, nasal sinuses, ears, tonsils, urinary tract, gall bladder, vermiform appendix, prostate, posterior urethra, etc., were examined for septic foci and cultures for the causal organism were made.

To diagnose the nature of the nodule, aqueous was withdrawn by a needlecannula (Amsler, 1951), centrifuged, and studied for bacteriological culture and cytology. The nodule was excised with a rim of iris around for histopathological examination.

Case 1, a 25-year-old male, had a left iris nodule (Fig. 1, opposite) of one week's duration. There was pyorrhoea alveolaris due to pneumococci. The aqueous showed a few polymorphonuclear cells and culture showed pneumococci. To learn the nature and prognosis only one-third of the nodule was excised.

Histopathological Examination.-The nodule showed subacute non-specific inflammatory tissue composed of polymorphonuclear cells and lymphocytes (Fig. 2, opposite). The section was negative for tuberculous reaction. The iris attached to the nodule showed also a subacute non-specific inflammation.

After another 3 weeks the aqueous fluid was sterile, containing no cells. The remaining part of the nodule was then excised; it showed a chronic non-specific granulation tissue composed of lymphocytes, plasma cells, and fibroblasts. The limbal incision healed quickly without signs of iritis. 


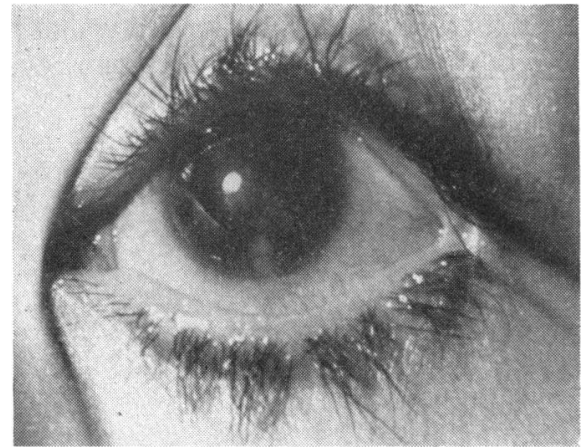

FIG. 1.-Case 1. Sub-acute non-specific inflammatory nodule of the left iris of one week's duration, caused by endogenous pneumococcal infection.

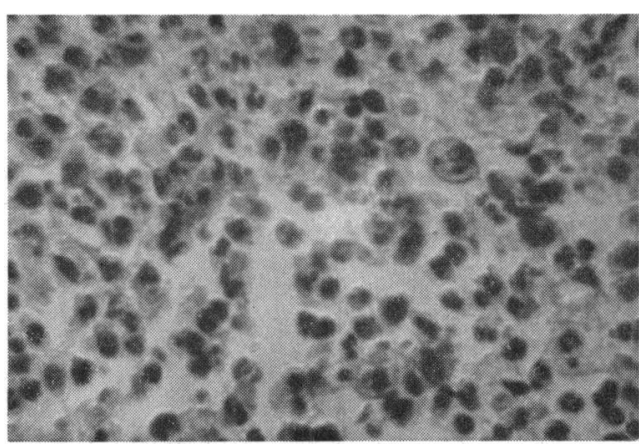

FIG. 2.-Case 1. Sub-acute non-specific inflammatory iris nodule, showing polymorphonuclear cells and lymphocytes. $\times 360$.

Case 2, a 20-year-old male, had a left iris nodule of 4 months' duration (Fig. 3) and a right iris nodule of 5 days' duration. The aqueous of the right eye showed Staphylococcus aureus and few polymorphonuclear cells. The right nodule showed a subacute nonspecific inflammatory tissue. The aqueous fluid from the left eye was sterile, containing no cells, and the nodule showed chronic non-specific inflammatory tissue (Fig. 4). A search for septic foci showed Staphyloccous aureus ethmoiditis.

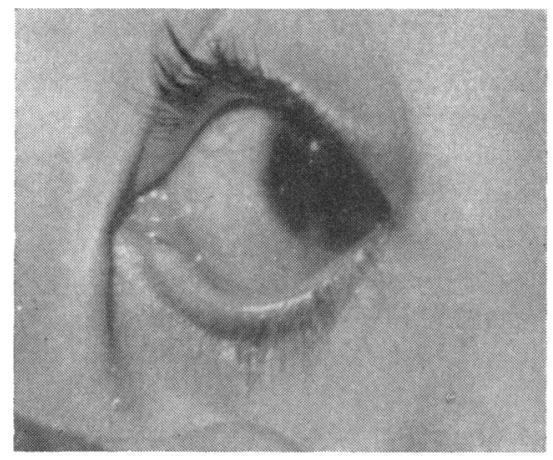

FIG. 3.-Case 2. Chronic non-specific granulomatous nodule of left iris of 4 months' duration caused by endogenous Staphylococcus aureus infection.

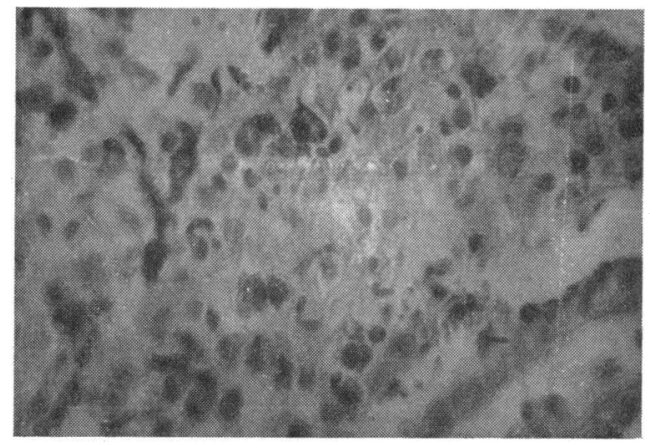

Fig. 4.-Case 2. Chronic non-specific left iris granuloma, showing plasma cells and lymphocytes. $\times 360$.

Case 3, a 30-year-old male, had a right iris nodule of 3 months' duration. The aqueous fluid was sterile, containing no cells. The nodule showed a chronic non-specific granulation tissue. There was Staphylococcus aureus infection of the right maxillary antrum.

Case 4, a 28-year-old male, had a left iris nodule of 5 months' duration, and 2 years before had had a perforating injury of the left eye by a lead foreign body. X rays showed a wire non-magnetic foreign body $3 \times 0.5 \mathrm{~mm}$. in the anterior segment of the left globe. There was no septic foci, and the aqueous fluid was sterile, containing no cells.

Histopathological Examination.-The nodule was diagnosed as a non-specific granuloma. The iris stroma spaces filled with degenerated blood cells appeared as large round 
or polygonal cells with the cytoplasm partly vacuolated and partly filled with fine and coarse eosinophilic granules (Figs 5 and 6). The periphery of the nodule was composed of mononuclear cells surrounded by fibrosis.

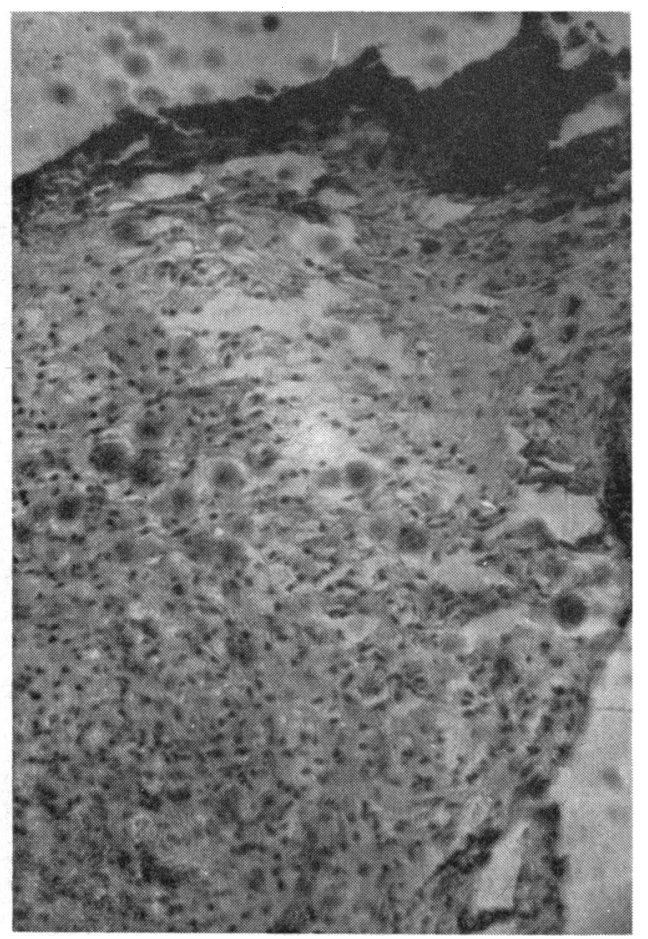

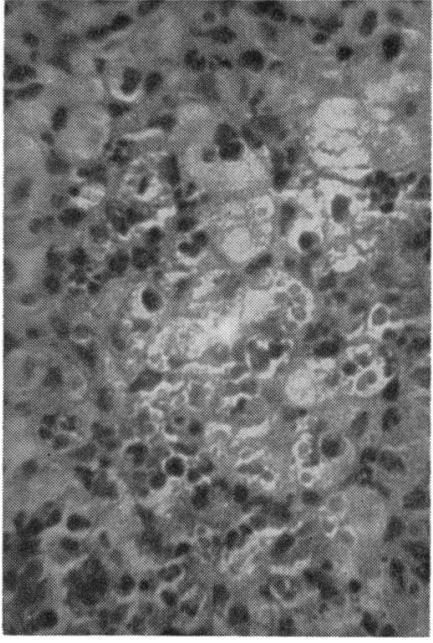

FIG. 6.-Case 4. Non-specific granuloma, showing iris stroma spaces appearing as cells partly vacuolated and partly filled with degenerated blood cells appearing as eosinophilic granules. $\times 360$.

Fig. 5.-Case 4. Non-specific granulomatous nodule caused by a lead foreign body impacted on the iris. $\times 120$.

The foreign body was not noticed during the excision of the nodule. The limbal incision remained ectatic for 2 weeks, however, and then the wire tip appeared spontaneously through the wound; after the wire was pulled out the incision healed.

In all four cases the cause was treated and 3 years' observation has shown no recurrence of iris nodules or iritis.

\section{Discussion}

The five histopathologically-diagnosed iris nodules were all non-specific granulomata, one being due to a lead foreign body impacted on the iris. A lead intra-ocular foreign body surrounded by a mass of inflammatory tissue of non-specific exudative type has been reported by Salva (1909), Oguchi (1913), Weigelin (1917), Winkler (1919), Wilder (1948), and other authors.

It is of interest that in the first case the iris nodule of one week's duration which was due to pneumococci showed a subacute inflammatory histology with polymorphonuclear leucocytes and might well have been called an iris abscess. When the remainder of this lesion was excised 3 weeks later it 
showed a chronic inflammatory histology of the type seen in so-called nonspecific iris granulomata.

In the second case the right iris nodule of 5 days' duration which was due to Staphylococcus aureus showed a subacute inflammatory histology, whereas the left iris nodule of 4 months' duration and, presumably, also of staphylococcal aetiology, showed a so-called granulomatous chronic inflammatory histology. The aqueous from the left eye was sterile at this time and this suggests that a staphylococcal aetiology was also possible in the third case in which the nodule had been present for 3 months.

These observations bear out the view of Ashton (1955). Metastatic pyogenic coccal infections in the iris must take their place alongside other causes of "granulomatous" iris nodules. It must be emphasized that none of the eyes discussed above presented clinical signs of acute inflammation.

\section{Summary}

(1) Non-specific iris granuloma due to low virulent pyogenic organisms of endogenous origin, though rarely recorded in the literature, is the commonest cause of an iris nodule in Egypt. The nodule is usually $3 \mathrm{~mm}$. in size, and is present on the anterior surface of the ciliary border of the iris, filling the angle of anterior chamber.

(2) Perhaps many cases diagnosed clinically as tuberculoma or gumma of the iris without histopathological examination, or diagnosed histopathologically as simple granular cell myoblastoma, are in fact cases of nonspecific iris granuloma.

\section{REFERENCES}

AMSLer, M. (1951). “XVI Conc. Ophthal. 1950, Britannia Acta”, vol. 1. 651. B.M.A., London. - and VerReY, E. (1943). Ophthalmologica (Basel), 105, 144.

Ashton, N. (1955). "XVII Conc. Ophthal. 1954, Canada, U.S.A. Acta”, vol. 2, p. 1214.

BusaccA, A. (1932). Klin. Mbl. Augenheilk., 88, 14.

DUKE-ELDER, S. (1940). "Text-book of Ophthalmology", vol. 3, p. 2198. Kimpton, London.

GoH, K. (1897). v. Graefes Arch. Ophthal., 43, Pt 1, p. 147.

HeINe, L. (1923). Klin. Mbl. Augenheilk., 71, 106.

HiguCHI, R. (1934). Ibid., 93, 348.

HORNER, W. D., and CORDES, F. C. (1931). Amer. J. Ophthal., 14, 628.

HOWARD, H. J. (1936). Arch. Ophthal. (Chicago), 15, 787.

Huber, A. (1951). "XVI Conc. Ophthal. 1950, Britannia Acta", vol. 1, p. 656. B.M.A., London.

Laval, J. (1937). Arch. Ophthal. (Chicago), 18, 104.

Lawson, L. J. (1933). J. Amer. med. Ass., 101, 599.

MYLIUS, K. (1926). Z. Augenheilk., 60, 147.

OGUCHI, C. (1913). Beitr. Augenheilk., 9, 75.

RaubitscheK, E. (1914). Klin. Mbl. Augenheilk., 52, 683.

SALVA, (1909). Clin. ophthal., 15, 373.

SÉDAN, J. (1935). Bull. Soc. franç. Ophtal., 48, 140.

VERREY, F. (1949). Ophthalmologica (Basel), 118, 461.

WeIGELIN, S. (1917). Klin. Mbl. Augenheilk., 59, 84.

WILDER, H. C. (1948). Amer. J. Ophthal., 31, 57.

WINKLER, E. M. (1919). Z. Augenheilk., 41, 60.

WolfF, E. (1951). "A Pathology of the Eye", 3rd. ed., p. 105. Lewis, London.

Wood, D. J. (1925). Trans. ophthal. Soc. U.K., 45, 724.

Woods, A. C. (1947). Amer. J. Ophthal., 30, 257. 